\title{
Changes in Selected Metals Concentrations from the Mid-1980s to the Mid-2000s in a Stream Draining the Picher Mining District of Oklahoma
}

\author{
William J. Andrews* ${ }^{* a, b}$ and Jason R. Masoner ${ }^{\mathrm{b}}$ \\ ${ }^{a}$ School of Civil Engineering and Environmental Science, Room 334, 202 W. Boyd Street, University of Oklahoma, \\ Norman, OK, 73019-1024, USA \\ ${ }^{b}$ U.S. Geological Survey, Oklahoma Water Science Center, 202 NW 66th Street, Bldg. 7, Oklahoma City, OK, 73116 \\ USA
}

\begin{abstract}
After abandonment in the late 1960s, the Picher mining district of Oklahoma, once the largest source of lead and zinc in the world, continued to be affected by severe environmental degradation, with scattered subsidence and abundant toxic metals such as cadmium and lead seeping from flooded underground mine workings and seeping and running off from as much as 60 million tons of mine tailings remaining at the land surface. Water-quality data collected during the mid-1980s and the mid-2000s at the Tar Creek at 22nd Street Bridge in Miami, Oklahoma streamflow-gaging station (USGS number 07185095), located downstream from much of the district, indicate that total concentrations of iron, manganese, and zinc significantly decreased between the two sampling periods. Those water-quality improvements probably are due to a combination of reclamation activities and natural attenuation processes such as stabilization of exposed minerals in flooded underground mine workings, progressive wind and water erosion of the most readily erodible metalliferous particles from tailings, and colonization of volunteer plants that reduce physical erosion of soils and tailings.
\end{abstract}

Keywords: Mining, metals, surface-water quality, natural attenuation, reclamation.

\section{INTRODUCTION}

\section{Brief History of Mining District}

The abandoned Tri-State mining district, a 3,077-squarekilometer area in southwest Missouri, southeast Kansas, and northeast Oklahoma, was the most productive site of mining for sulfide ores of lead and zinc in the U.S. from the late 1830 s to the 1970 s, producing about 1.7 million tons of lead and 8.8 million tons of zinc [1-4]. Parts of the mining district, included in the initial National Priority List of Superfund sites by the U.S. Environmental Protection Agency in 1983, are affected by some of the most severe and widespread environmental degradation of any of the tens of thousands of abandoned mining sites in the U.S. [3-5].

The Picher mining district (the Oklahoma part of the TriState mining district shown in Fig. 1) is an approximately 100-square-kilometer area in Ottawa County, Oklahoma that was the site of mining for ores of lead and zinc sulfide minerals primarily during the first half of the 20th century. From the early 1900 s to 1950 , the Picher mining district produced 5.2 million tons of zinc and 1.3 million tons of lead [6]. By 1926, the peak year of production, Ottawa County, Oklahoma was the world's largest source of lead and zinc [7]. From 1908 through 1930, mines in the Picher mining district and neighboring mining districts in Kansas and Mis-

*Address correspondence to this author at the School of Civil Engineering and Environmental Science, Room 334, 202 W. Boyd Street, University of Oklahoma, Norman, OK, 73019-1024, USA; Tel: 405-635-4437; Fax: 405325-4217; E-mail: William.J.Andrews-1@ou.edu souri produced a total of more than $\$ 222$ million worth of zinc and $\$ 88$ million of lead, including more than 50 percent of the zinc and 45 percent of the lead needed in World War I [7].

The Picher mining district, much of which drains south via Tar Creek, contains the largest remaining accumulation of mine tailings in the Tri-State mining district (as much as 60 million tons) (Figs. 1 and 2). The quantity of mine tailings on the land surface has decreased with time due to gradual removal of tailings for use as aggregate for roads and other purposes [8]. When mining stopped in 1970, between 165-300 million tons of metals-rich mine tailings remained in the district [13]. As of 2000, as much as 75 million tons of mine tailings remained [3]. After mining ceased, dewatering pumps were turned off and the original mine workings refilled with water, with groundwater eventually seeping out to the land surface from the mine workings in 1979 [3].

Mine tailings in the abandoned Picher mining district contain thousands to tens of thousands of milligrams per kilogram $(\mathrm{mg} / \mathrm{Kg}$, or parts per million) of aluminum, iron, lead, and zinc. Finer particles in tailings, which are more likely to be mobilized by air and water, tend to contain the greatest metals concentrations (Table 1) [10, 11]. Although the number of samples analyzed for metals concentrations listed on Table $\mathbf{1}$ is small, similar concentrations were reported for concentrations of cadmium, lead, and zinc in many of the 56 tailings samples collected from a local tailings pile and in samples collected from 6 tailings piles in the Tar Creek Basin [10, 11]. 


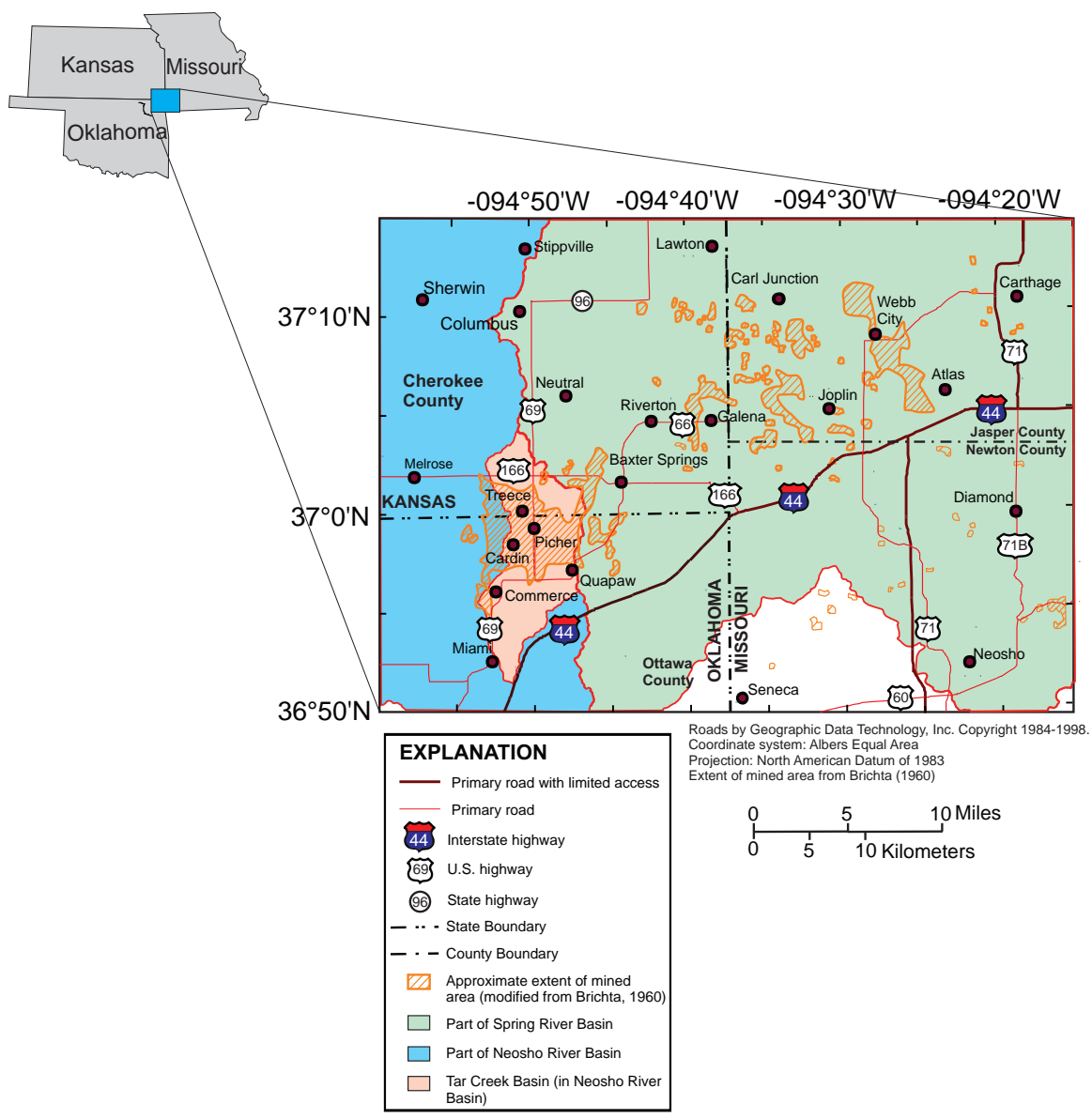

Fig. (1). Location of the Tri-State mining district [9].

Leachate and runoff from tailings and contaminated soils and seepage from metals-contaminated groundwater in flooded underground mine workings discharges to streams draining the district, with the primary drainage being to Tar Creek (Fig. 2). Along Tar Creek, about 5 miles upstream from the streamflow-gaging station at the 22nd Street Bridge, as much as 99 percent of iron loading was from mine outflows, with lesser proportions of zinc (19 percent), lead (51 percent), and cadmium (68 percent) in the creek being from leachate from mine tailings rather than mine outflows [12].

Monitored natural attenuation may be a useful method for reclamation of abandoned mining areas in conjunction with more active reclamation methods [13]. In addition to removal of tens of millions of tons of metals-rich mine tailings over the past several decades for economic and/or reclamation purposes, local streams may have flushed many tons of particulate and dissolved metals downstream. Relatively mobile dissolved metals may have been sequestered in local soils and streambed sediments in less mobile forms such as in oxide, hydroxide, oxyhydroxide, and carbonate minerals [13-15]. Conversely, disturbance and transport of relatively stable piles of mine tailings and subsequent oxidation of relatively immobile metallic sulfide minerals may have increased mobility of metals in the environment in the past several decades [11].

Table 1. Concentrations of Selected Metals in a Tailings Sample from a Tailings Pile and Two Millpond Fine Tailings Samples Collected Near Cardin, OK in 2004

\begin{tabular}{|c|c|c|c|}
\hline \multirow{2}{*}{ Metal } & \multicolumn{2}{|c|}{ Tailings Pile Sample } & \multirow{2}{*}{$\begin{array}{c}\text { Mean of two Millpond Fine Tailings Samples, } \\
\text { Metal Concentration, in mg/Kg (Unsorted) }\end{array}$} \\
\cline { 2 - 4 } & Unsieved Concentration, in $\mathbf{~ m g / K g}$ & Sieved Concentration (<2 mm), in $\mathbf{~ m g / K g}$ & 20,300 \\
\hline \hline Aluminum & 1,700 & 4,100 & 119 \\
\hline Cadmium & 12.9 & 31.2 & 16,900 \\
\hline Iron & 1,690 & 4,080 & 9,180 \\
\hline Lead & 369 & 890 & 158 \\
\hline Manganese & 13.8 & 33.2 & 22,300 \\
\hline Zinc & 3,630 & 8,750 & \\
\hline
\end{tabular}

[Analyses by digestion and ICP-MS, U.S. Geological Research Laboratory, Denver, Colorado, written commun., Stephen J. Sutley, 2005]. 


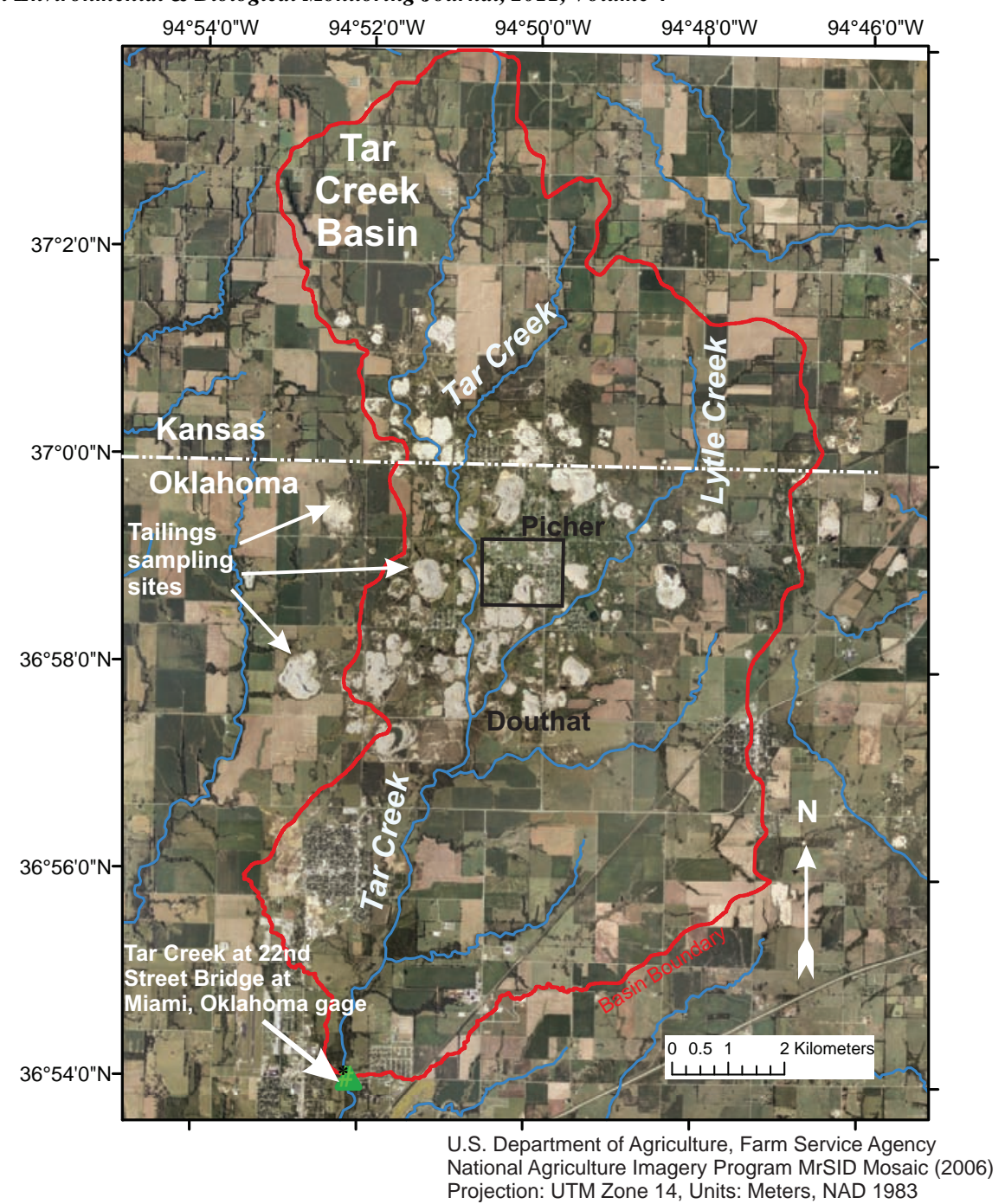

Fig. (2). Aerial photograph of the Tar Creek Basin upstream from the 22nd Street Bridge in Miami, Oklahoma gaging station.

\section{Purpose and Scope}

The purpose of this paper is to investigate whether significant changes in surface-water quality have occurred between the mid-1980s and the mid-2000s in the abandoned Picher mining District of northeastern Oklahoma. The data described in this report were collected during two sampling periods: from February 1984 through February 1986 (mid1980s) [16] and from June 2004 through April 2006 (mid2000s) by the U.S. Geological Survey (USGS) and the Oklahoma Department of Environmental Quality (ODEQ).

The sampled station is on the main drainage of this mining district, downstream from most known historical mining activities and thus integrates the effects of mining, reclamation, and other land uses occurring in mined and other upstream parts of this basin. That station also has the most streamflow and water-quality data of all sampled sites near the mining district during these and other time periods. Results of this analysis should indicate whether processes related to natural attenuation and reclamation are causing longterm reductions in concentrations of metals discharging in stream draining a large abandoned mining district on a time scale of two decades.

\section{MATERIALS AND METHODOLOGY}

\section{Sampling}

Although evaluating trends in data gathered from regular periodic sampling at the station over several decades would have been informative, such data were not available. Two intensive data-collection periods occurred at this station in the mid-1980s and the mid-2000s, facilitating investigation of changes in water quality between those two periods at that station.

In the mid-1980s, the USGS collected 25 water samples for analysis of metals concentrations at the station [15]. In the mid-2000s, the USGS, in cooperation with the Oklahoma Department of Environmental Quality (ODEQ) and the U.S. Environmental Protection Agency (USEPA), collected 22 water-quality samples at the station.

Streamflow and selected water-quality parameters were measured in the field using USGS protocols [17-20]. Chemical analyses of unfiltered water samples by flame atomic absorption spectrometry was done in the mid-1980s at the USGS National Water-Quality Laboratory in Lakewood, Colorado [17, 21]. Unfiltered, acid-preserved surface-water samples collected by USGS and ODEQ staff in the mid- 
2000s were digested and analyzed by inductively-coupled plasma-atomic emission spectrometry with Thermo Jerrell Ash Trace ICP Analyzer ${ }^{\star}$ at the U.S. Environmental Protection Agency-certified ODEQ Laboratory in Oklahoma City, Oklahoma, using methods described in USEPA Method 2007 [22]. Streamflow and water-quality data described in this paper are available in the USGS National Water Information System (http://waterdata.usgs.gov/nwis).

\section{Data Analysis}

Graphs of metals concentrations versus streamflow were made with the S-Plus 7.0 statistical and graphing package [23]. Censored (less than the level of quantification also known as the reporting level) data values were estimated to be one-half of the laboratory reporting level for graphs of metals concentration data versus streamflow and are shown using different symbols.

Estimation of similarities of locations of distributions of data in sample groups were done using the two-sample Wilcoxon rank sum test with approximate distribution and continuity correction, a mean of zero under null hypothesis, and an alternative hypothesis of "greater than" using the S-Plus 7.0 software package [24]. P-values of this test are a measure of likelihood that the null hypothesis (no difference between numbers of two groups) is true. An alpha level of 0.05 or less for one sided p-values supports a 95 percent or greater confidence that the locations of distributions of two groups of numbers are different (the alternative hypothesis). A p-value of 0.10 or less indicates a 90 percent or greater confidence that the locations of distribution of two groups of numbers of different. The Z-value of the Wilcoxon rank sum test is the sum of deviation of each data value from a group mean divided by the standard deviation of the group.

Although substantial portions of total aluminum and lead data were censored (non-detects), censored values (reporting levels) were retained in the data sets for analysis by the Wilcoxon rank sum test, rather than adjusted, because the test is non-parametric (relies on ranking of data, rather than absolute data values).

\section{Quality Assurance/Quality Control}

In the mid-1980s, several samples were collected at the same sites at intervals of an hour or more between samples, but no field quality-assurance samples such as split samples, duplicates collected within short time intervals, or field or equipment blanks were collected, which was typical of many sample collection projects collected during that period (oral commun. David Parkhurst, U.S. Geological Survey, 9/12/2008; oral commun. Jon Scott, U.S. Geological Survey, 9/12/2008) [16].

In the mid-2000s, several types of quality-assurance samples were collected at the station. Equipment blanks for major ions and metals were collected using metals-grade blank water prior to data collection. Analyzed metals were not detected in those equipment blanks. One field blank and two field duplicate samples were collected at the station (frequencies of about 5 and 10 percent of field samples, respec-

\footnotetext{
$\$$ Any use of trade, firm, or product names is for descriptive purposes only and does not imply endorsement by the U.S. Government
}

tively). No metals were detected in the field blank. Relative percent differences between metals concentrations in the two field duplicate samples ranged from 0 to 10.5 percent.

\section{RESULTS}

\section{Streamflow}

Mean daily streamflow at the station was significantly greater during the mid-1980s sampling period than in the mid-2000s sampling period (Figs. 3 and $\mathbf{4}$, Wilcoxon rank sum test $\mathrm{Z}=10.3, \mathrm{p}=<0.01)$. However, streamflows at the times of collection of water-quality samples were not significantly different at an alpha value less than or equal to 0.10 between the two sampling periods (Fig. 5, Wilcoxon rank sum test $\mathrm{Z}=1.39, \mathrm{p}=0.0829$ ). Because of the similarity in streamflow values at times of sampling between the two periods, metals concentrations were not adjusted for differences in flow conditions at the times of sampling.

\section{pH}

As with all Mississippi Valley-type mining districts, this district is underlain by carbonate host rocks [25,26]. Dissolution of the carbonate rocks tends to buffer acids formed during oxidation of iron and other metals. Buffering occurs during the oxidation of ferrous iron to form minerals such as ferric hydroxide and goethite, as expressed by the following reaction equations [27-29].

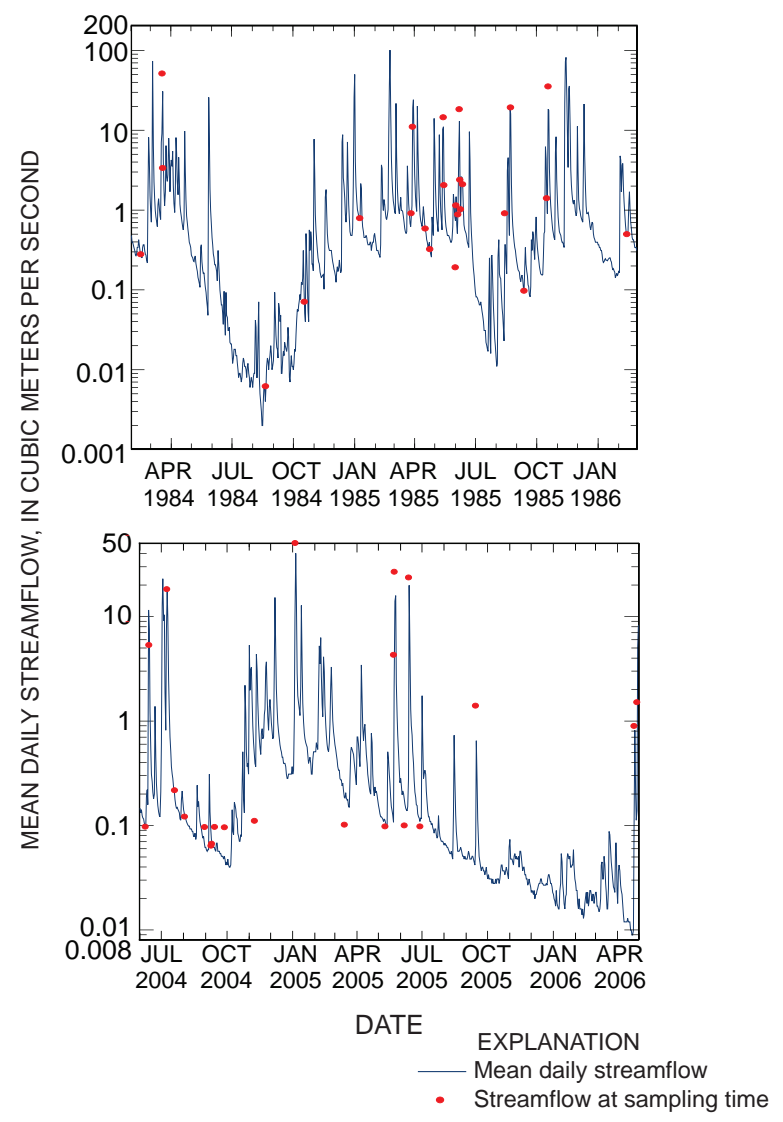

Fig. (3). Hydrographs of mean daily streamflow from February 1984 through February 1986 and from June 2004 through April 2006, at the Tar Creek at 22nd Street Bridge at Miami, Oklahoma gaging station. 


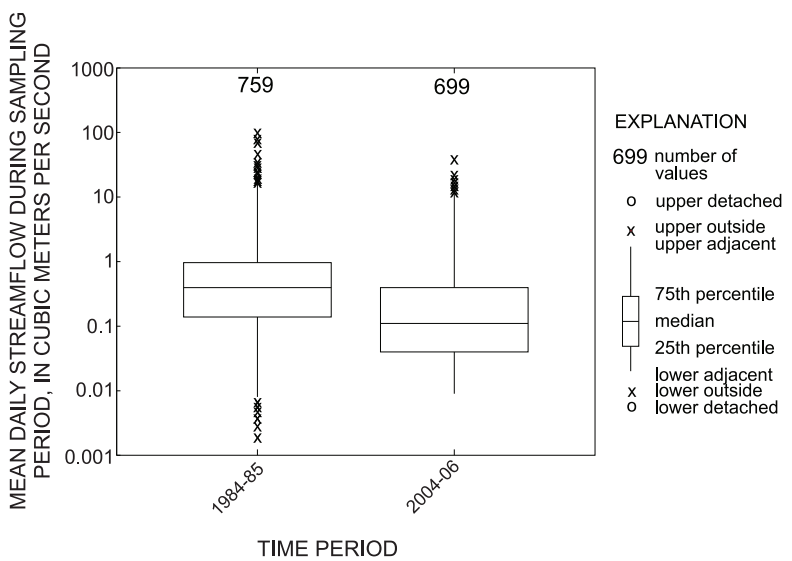

Fig. (4). Boxplots of mean daily streamflow, February 1984 through February 1986 and from June 2004 through April 2006, at the Tar Creek at 22nd Street Bridge at Miami, Oklahoma gaging station.

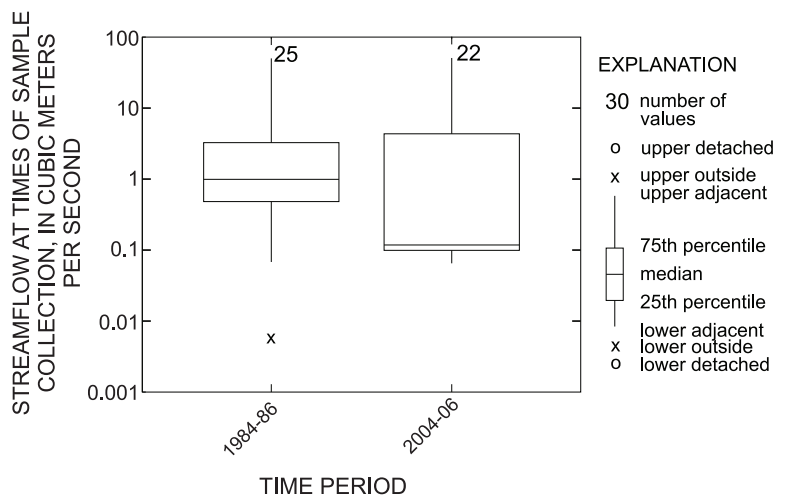

Fig. (5). Boxplots of streamflow at time of sampling, February 1984 through February 1986 and June 2004 through April 2006, at the Tar Creek at 22nd Street Bridge at Miami, Oklahoma gaging station.

$$
\begin{aligned}
& 2 \mathrm{FeS}_{2} \text { (solid marcasite) }+7 \mathrm{O}_{2}(\mathrm{~g})+2 \mathrm{H}_{2} \mathrm{O}(\mathrm{l}) \rightarrow 2 \mathrm{Fe}^{+2} \text { (aq) }+4 \mathrm{SO}_{4}^{-2} \text { (aq) } \\
& +4 \mathrm{H}^{+}(\mathrm{aq}) \text {, } \\
& \mathrm{Fe}^{+2}(\mathrm{aq})+2 \mathrm{H}_{2} \mathrm{O}(\mathrm{l}) \rightarrow \mathrm{Fe}(\mathrm{OH})_{2}(\mathrm{~s})+2 \mathrm{H}^{+}(\mathrm{aq}), \\
& \mathrm{Fe}(\mathrm{OH})_{2}(\mathrm{~s})+\mathrm{H}_{2} \mathrm{O} \rightarrow \mathrm{Fe}(\mathrm{OH})_{3}(\mathrm{~s})+\mathrm{H}^{+}(\mathrm{aq})+\mathrm{e}-, \\
& \mathrm{H}_{2} \mathrm{O}(1) \text {, }
\end{aligned}
$$

With time, fresh, reactive surfaces of metallic sulfide mineral crystals undergo reactions such as those in the previous equations, forming hydroxides, oxyhydroxides, and hydroxysulfate minerals, with other dissolved metals commonly sorbing onto surfaces of those minerals $[13,30]$. Such reactions, along with carbonate buffering and formation of metallic carbonate minerals, should neutralize acidity, increasing stability of metallic hydroxide precipitates [31].

$\mathrm{pH}$ significantly increased between the two sampling periods (Wilcoxon rank sum test $Z=4.29, p=<0.001$, Fig. 6). The general increase in $\mathrm{pH}$ in water at this station may be due to the geochemical processes previously described. Slight increases of $\mathrm{pH}$ with streamflow at this station may be the result of buffering caused by runoff of calcareous minerals from tailings in upstream parts of this basin.

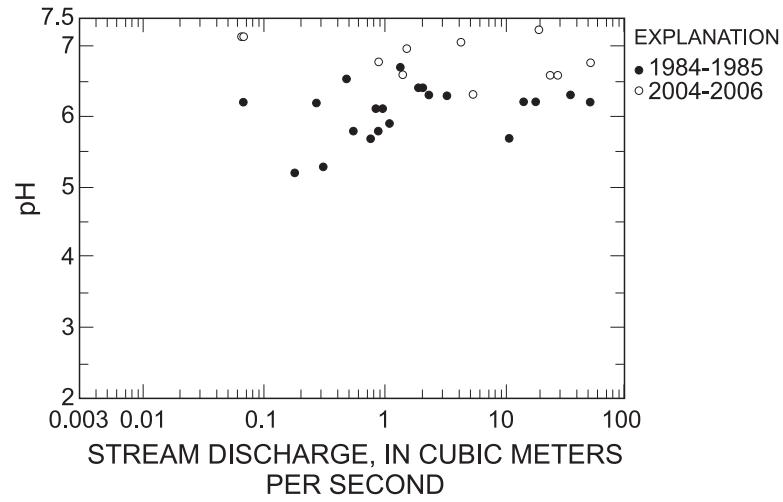

Fig. (6). Graph of $\mathrm{pH}$ versus streamflow, February 1984 through February 1986 and June 2004 through April 2006, at the Tar Creek at 22nd Street Bridge at Miami, Oklahoma gaging station.

\section{Metals Concentrations}

\section{Aluminum}

Aluminum in sedimentary rocks most commonly occurs in the form of clay minerals, and in water is typically associated with suspended particles of aluminosilicate or hydroxide minerals, rather than being dissolved as a metallic ion [27]. Although there are tens of thousands of $\mathrm{mg} / \mathrm{Kg}$ of aluminum in local fine tailings, aluminum in Tar Creek also may be derived from erosion of clay minerals from the Mississippian-age Krebs formation, which underlies the land surface in most of the Tar Creek Basin [25]. Re-suspension of clays in streambed sediments may be an important mechanism causing exponential increases in total aluminum concentrations with increasing streamflow (Fig. 7). Aluminum concentrations were not significantly different between the two sampling periods (Wilcoxon rank sum test score $\mathrm{Z}=0.680, \mathrm{p}=0.248$ ), indicating relatively constant sources of aluminum in this basin.

\section{Iron}

Iron typically occurs in oxidized, circum-neutral $(\mathrm{pH} 7)$ water as particles of iron oxides and oxyhydroxides, whereas in reducing conditions that are more common in groundwater, iron is more likely to be present in the dissolved phase as the ferrous $\left(\mathrm{Fe}^{+2}\right)$ ion or precipitated as sulfide minerals such as marcasite and pyrite [27]. The iron sulfide minerals marcasite and pyrite were ubiquitous in now-flooded underground mine workings and tailings piles on the land surface

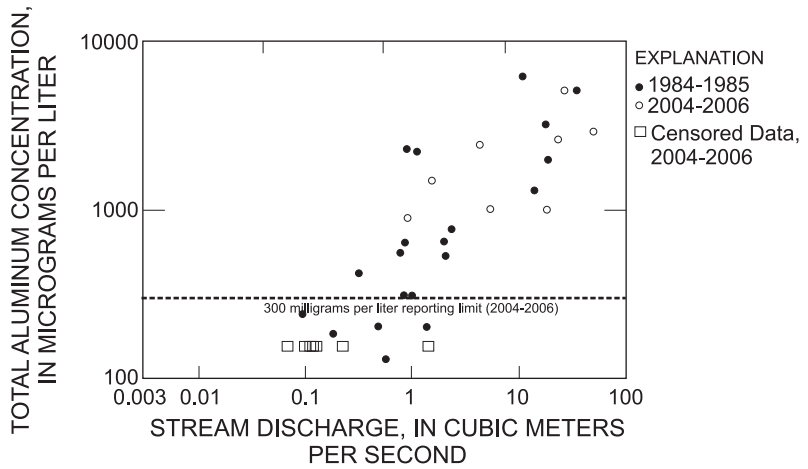

Fig. (7). Total aluminum concentrations versus streamflow, February 1984 through February 1986 and June 2004 through April 2006, at the Tar Creek at 22nd Street Bridge at Miami, Oklahoma gaging station. 

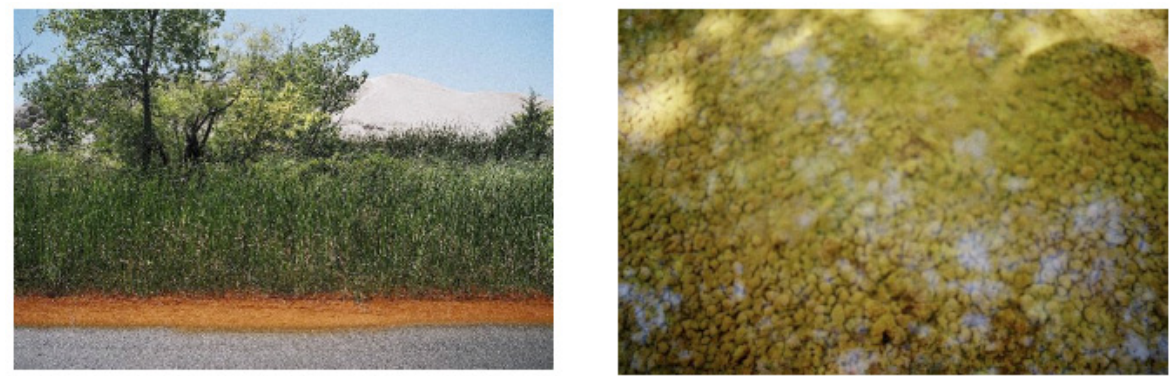

Fig. (8). Photographs of iron oxide and hydroxide deposits at a roadside ditch and on the bed of Tar Creek at Douthat, Oklahoma, 2003-2006 (W.J. Andrews photos).

in the Picher mining district [25]. As those minerals gradually dissolve, substantial concentrations of ferrous iron seep in water discharged from the mine workings and tailings to local streams [12, 32, 33].

Oxidizing conditions in those streams lead to formation and precipitation of 0.5 meters or more of thick goethite-rich sediments on the beds of many streams draining the district (Fig. 8). Similar to aluminum, fine mine tailings in the district contain thousands to tens of thousands of milligrams per kilogram of iron (Table 1), which can be flushed into local streams by runoff, but nearly all of the metal load in upstream parts of the creek were from seepage of iron-rich ground water from the flooded underground mines [12].

Iron concentrations at the station significantly increased by a factor of about 5 from the mid-1980s to the mid-2000s (Wilcoxon rank-sum test statistic $\mathrm{Z}=5.30, \mathrm{p}=<0.001$ ). Reasons for the decreases in iron concentrations in Tar Creek may include:

(1) relatively anoxic conditions after several decades of flooding of the mine workings not being as conducive to oxidation and dissolution of remaining iron-sulfide minerals, [30, 31]

(2) the most accessible of those minerals on surfaces of the underground workings being either dissolved and flushed from the system over that period and/or having been stabilized by coatings of iron oxide, hydroxide, and carbonate minerals, and

(3) easily eroded small particles of iron may have been: a) flushed through the system during that period, b) stabilized as concretions of ferric minerals, and/or c) become

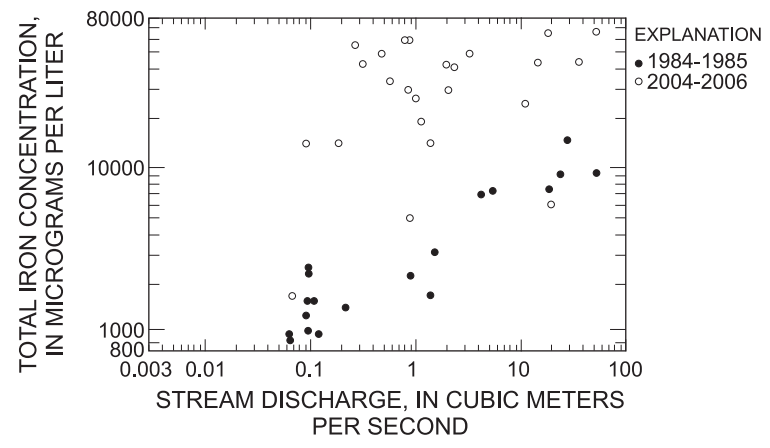

Fig. (9). Total iron concentrations versus streamflow, February 1984 through February 1986 and June 2004 through April 2006, at the Tar Creek at 22nd Street Bridge at Miami, Oklahoma gaging station. less erodible due to stabilization by colonizing by volunteer plants (Fig. 10).

The tendency for increasing iron concentrations with streamflow, particularly for water-quality samples collected in the mid-2000s (Fig. 9), indicate that runoff of iron-bearing particles from the land surface and/or re-suspension of ironrich streambed sediments may be transport agents of iron to the water column at this station. Another source of increased iron concentration with increasing streamflow, however, may be increased discharge from flooded mine workings during wetter periods, which may comprise as much as 99 percent of iron in upstream parts of Tar and Lytle Creeks [12].

\section{Manganese}

The chemistry of manganese is somewhat similar to that of iron, though manganese is less abundant in the earth's crust by a factor of 50 [27]. Hydrous oxides of iron and man-
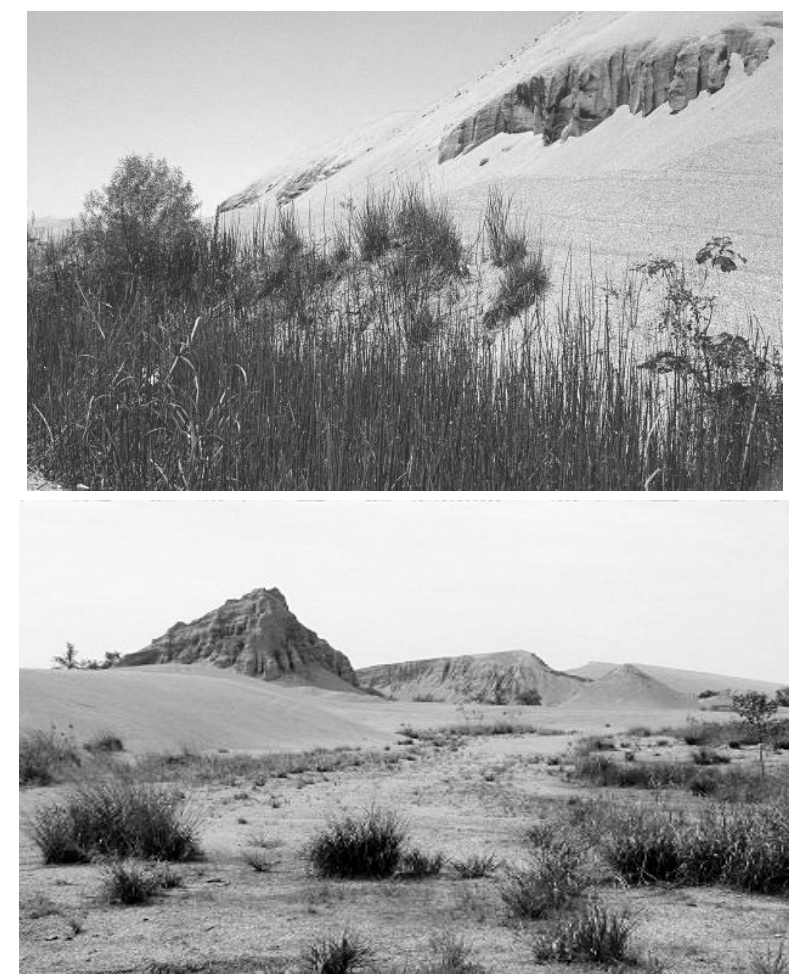

Fig. (10). Grasses invading previously bare mine tailings in the mining district at a tailings pile at Douthat, Oklahoma in August 2004 and a tailings pile near Picher, Oklahoma in July 2003 (W.J. Andrews photos). 


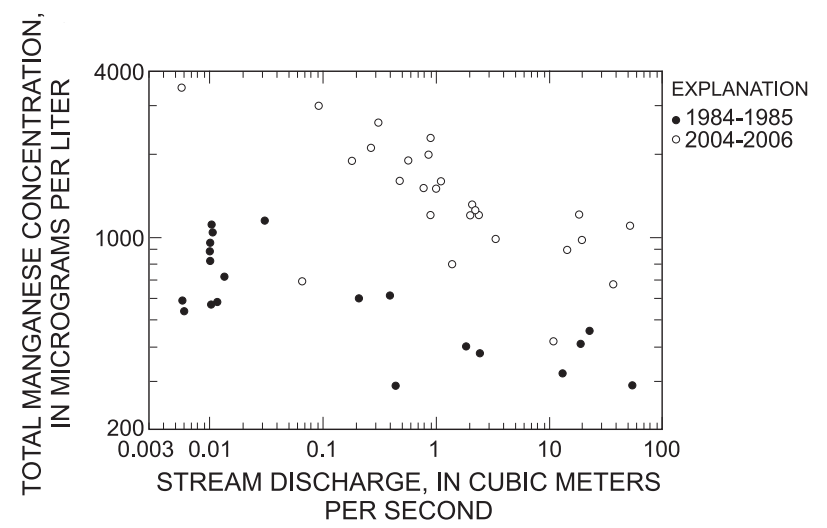

Fig. (11). Total manganese concentrations versus streamflow, February 1984 through February 1986 and June 2004 through April 2006, at the Tar Creek at 22nd Street Bridge at Miami, Oklahoma gaging station.

ganese are important substrates for sorption of other metals in aquatic environments, though the reduced manganous $\left(\mathrm{Mn}^{+2}\right)$ ion is more stable than the ferrous $\left(\mathrm{Fe}^{+2}\right)$ ion in aerated water, meaning that manganese will precipitate more slowly in such water than iron $[27,31]$.

Like iron, manganese concentrations decreased significantly from the mid-1980s to the mid-2000s (Fig. 11, Wilcoxon rank-sum test statistic $\mathrm{Z}=4.65, \mathrm{p}=<0.001$ ) by a factor of about 4. Decreases of total manganese concentrations with increasing streamflow indicate that relatively little manganese is precipitating in streambed sediments, with manganese seeping from anaerobic groundwater being diluted during higher streamflows/runoff events.

\section{Lead}

Although lead was one of the two primary minerals extracted during mining in this district, lead generally is less mobile in water than other metals due to its propensity to precipitate as sulfide, carbonate, hydroxycarbonate, and phosphate minerals; to absorb to organic and inorganic sediment surfaces; and to co-precipitate with manganese oxide [27]. Changes in lead concentrations between the two sampling periods are largely masked by a much higher reporting level (10 ug/L) for samples collected during the mid2000s compared to the $0.1 \mathrm{ug} / \mathrm{L}$ reporting level for samples collected during the mid-1980s (Fig. 13). The Wilcoxon rank-sum test statistic $(\mathrm{Z}=-1.60, \mathrm{p}=0.945)$ indicated no significant difference in lead concentrations between the sampling periods. Occurrence of greater concentrations of lead at greater streamflows indicate that runoff of lead particles on the land surface or re-suspension of lead-bearing streambed sediments during higher streamflows are likely to be the principal transport agents of lead to the water column of this stream, similar to results described in the upstream part of this basin [12].

\section{Zinc}

Zinc was the primary metal mined from the Picher mining district and remains in concentrations of tens of thousands of $\mathrm{mg} / \mathrm{Kg}$ (parts per million) in fine mine-tailing particles [10]. Zinc concentrations were generally greater than aluminum, lead, and manganese concentrations, and zinc occurred in significantly greater concentrations in the mid-

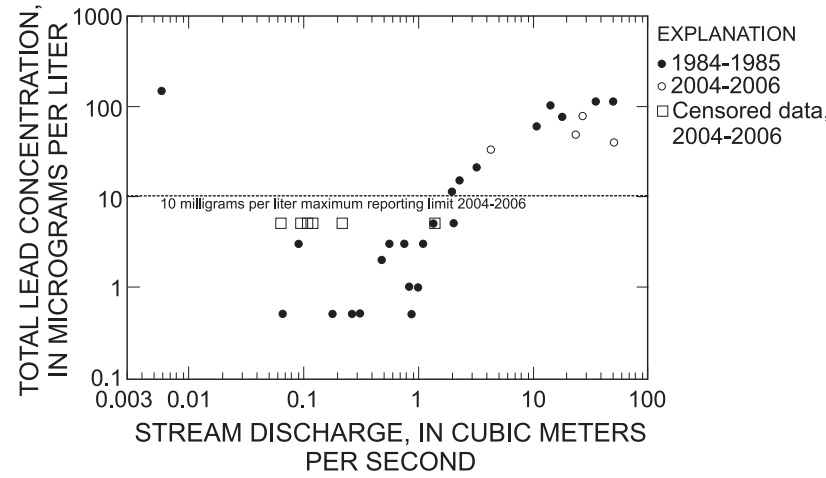

Fig. (12). Total lead concentrations versus streamflow, February 1984 through February 1986, and June 2004 through April 2006, at the Tar Creek at 22nd Street Bridge at Miami, Oklahoma gaging station.

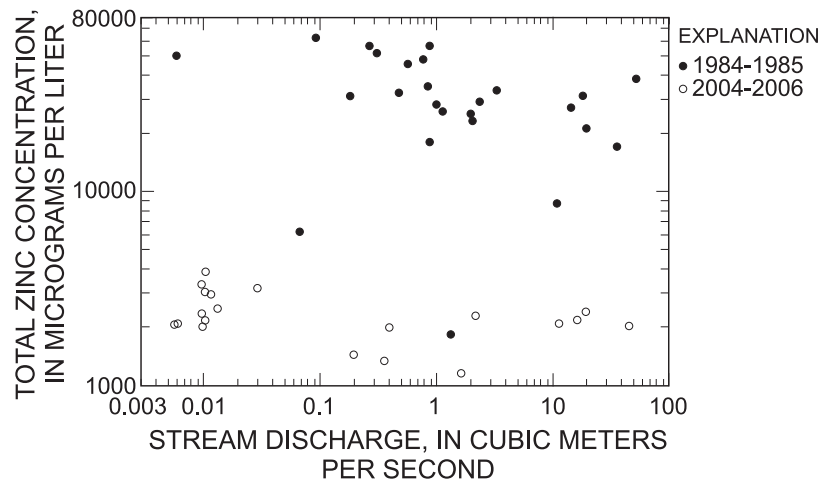

Fig. (13). Total zinc concentrations versus streamflow, February 1984 through February 1986 and June 2004 through April 2006, at the Tar Creek at 22nd Street Bridge at Miami, Oklahoma gaging station.

1980s (Wilcoxon rank sum test statistic $Z=5.45, \mathrm{p}<0.001$ ) than in the mid-2000s at this station (Figs. 7, 11, 12, and 13). Zinc concentrations were generally greater than aluminum, lead, and manganese concentrations, and zinc occurred in significantly greater concentrations in the mid-1980s (Wilcoxon rank sum test statistic $Z=5.45, \mathrm{p}<0.001$ ) than in the mid-2000s at this station (Figs. 7, 11, 12, and 13). Zinc concentrations at similar streamflows decreased by about a factor of 10 between the two sampling periods (Fig. 13).

As sphalerite $(\mathrm{ZnS})$, which was the primary ore of zinc in the district, dissolves and seeps out of the mine workings, the released zinc tends to oxidize, forming relatively insoluble zinc oxides (such as zincite $\mathrm{ZnO}$ ), hydroxides (such as $\mathrm{Zn}(\mathrm{OH}) 2$ ), zinc hydroxycarbonate minerals (such as hydrozincite, $\left.\mathrm{Zn}(\mathrm{OH})_{6}\left(\mathrm{CO}_{3}\right)_{2}\right)$, and complexes with iron hydroxide minerals, particularly in well-buffered carbonate systems common in this and other Mississippi River Valley-type deposits (oral commun., Dr. Paul L. Younger, Newcastle University (U.K.), 3/2006) [14, 15, 26, 27, 34, 35].

Smaller zinc concentrations at greater streamflows for both sampling periods (Fig. 13) indicate that, like manganese, the primary source of total zinc in water at the station may be seepage of groundwater from flooded underground mine workings [12]. 


\section{DISCUSSION AND CONCLUSIONS}

Natural attenuation through flushing of metals, transformation of metals into less soluble and bioavailable forms, and uptake of metals into plants has the potential to eventually reduce concentrations of metals in the decades after abandonment of mining districts and similar metalliferous industrial sites $[11,13]$.

Colonization of mined areas by volunteer plants (Fig. 10) also has stabilized tailings and metals-contaminated soils, possibly reducing runoff metals to local streams. Natural flushing and chemical stabilization of metals in mine tailings and the underground mine workings also may have played a part in reducing metals discharges to Tar Creek.

Some reclamation has been occurring in the Picher mining district in the decades after its closure in the early 1970s. Tens of millions of tons of mine tailings have been removed for commercial uses [3, 10,36]. Dikes and diversion structures were installed several miles upstream on Tar Creek near Douthat, Oklahoma in the late 1980s, with goals of: (a) reducing the volume of surface water flowing into the mine workings through open mineshafts, and (b) reducing discharges of metals-rich water from the mines to local streams [37]. Quantities of water discharging from mine seeps in the Oklahoma part of the mining district tended to decrease in the 1990s and 2000s (oral commun., Dr. Robert W. Nairn, University of Oklahoma, 9/11/2008), but the reasons for decreases in those discharges may be complex, being due to relations between changes in recharge, other natural causes such as collapses and eventual plugging of seep conduits, and reclamation activities such as diverting local streams from flowing into mineshafts, and plugging abandoned mineshafts and prospect borings. Planned burial of metalsrich fine tailings in the flooded underground mine workings may reduce runoff of metals from the land surface in the mining district, but has an uncertain potential for contributing metals to ground-water-flow systems underlying the mining district [8].

From the mid-1980s to the mid-2000s, no significant changes occurred in the concentrations of aluminum and lead, whereas significant decreases in total concentrations of iron, manganese, and zinc occurred in water samples collected at the stationon Tar Creek. Changes in lead concentrations, however, may have been masked by a much greater reporting limit during the second sampling period in the mid2000s. Iron, manganese, and zinc are relatively mobile metals which may seep from sulfide minerals in flooded underground mine workings and tailings piles and/or runoff from mine tailings and contaminated soils. Significant decreases in the concentrations of those metals at this station between the two sampling periods indicate that environmental conditions in the Picher mining district are gradually improving, probably due to a combination of natural attenuation processes and human reclamation activities.

No significant decreases occurred in the concentrations of aluminum (which may be primarily eroded from a surficial geologic unit unrelated to the mining). Aluminum, iron, and lead concentrations tended to increase with streamflow, indicating that runoff and/or re-suspension of streambed sediments containing those metals may be important sources of those metals at higher flows. Tendencies for decreasing concentrations of manganese and zinc at higher streamflows indicate that seepage from flooded underground mine workings and other groundwater may be more important sources of those metals, which are diluted in concentration by runoff.

Water-quality improvements occurring in this abandoned mining district from the mid-1980s to the mid-2000s are likely to be due to a combination of natural attenuation processes and reclamation activities, including:

a) natural flushing and geochemical stabilization of iron, manganese, and zinc in oxidizing conditions at the land surface and anaerobic conditions in the flooded underground mine workings,

b) colonization of mined areas by volunteer plants which stabilize tailings and metals-contaminated soils, and reduce runoff and seepage of metals to local streams;

c) and to reclamation activities, such as:

1) removal of tens of millions of tons of mine tailings,

2) pilot projects to inject metals-rich fine particles in mine tailings into the flooded underground mine workings, and

3) alteration of stream courses and seeps to reduce recharge of flooded underground mine workings.

\section{ACKNOWLEDGMENTS}

The authors wish to acknowledge Dr. David L. Parkhurst for his early work in evaluating water and sediment quality in the Picher mining district. The authors also thank Mark F. Becker and the USGS and DEQ technicians who collected the water-quality samples summarized in this paper. Appreciation is also extended to Dr. Kim T. Winton, Dr. Stan Paxton, Jerrod Smith, Victoria Christensen, and Keith Lucey of the USGS for their helpful suggestions during preparation of this manuscript.

\section{REFERENCES}

[1] Gibson AM. Wilderness bonanza-The Tri-State district of Missouri, Kansas, and Oklahoma. Norman, OK: University of Oklahoma Press 1972; p. 362.

[2] Gibson AM. In: Morris JW, Ed. Lead and zinc. Drill bits, picks, and shovels-A history of mineral resources in Oklahoma. Oklahoma City, Oklahoma: Oklahoma Historical Society 1982.

[3] State of Oklahoma, Governor Frank Keating's Tar Creek Superfund Task Force, Final Report. Office of Secretary of Environment 2000; p. 68.

[4] Robertson D. Hard as the rock itself, place and identity in the American mining town. Boulder, Colorado: University Press of Colorado 2006; p. 232.

[5] Ferderer DA. National overview of abandoned mine land stations utilizing the Minerals Availability System (MAS) and geographic information system (GIS) technology. U.S. Geological Survey Open-File Report 96-549 1996; p. 42.

[6] Stewart DR. In: Association of Missouri Geologists, Eds. A brief description of the historical, ore production, mine pumping, and prospecting aspects of the Tri-State zinc-lead district of Missouri, Kansas, and Oklahoma. Guidebook to the geology and environmental concerns in the Tri-State lead-zinc district, Missouri, Kansas, and Oklahoma. Association of Missouri Geologists, 33rd annual field trip. September 26-27 1986. 
[7] Everett D. Tri-State Lead and Zinc District: Oklahoma Historical Society. [monograph on the internet]. Oklahoma City, OK: Oklahoma History Museum 2004 [cited 2004 May 2]. Available from: http://www.ok-history.mus.ok.us/enc/tri-statemines.htm/

[8] U.S. Environmental Protection Agency. Criteria for the safe and environmentally protective use of granular mine tailings known as "chat", Final Rule-July 18, 2007. U.S. Environmental Protection Agency; 2007 [cited 2008 July 2]. Available from: http://www.epa.gov/epaoswer/other/mining/chat/

[9] Brichta LC. Catalog of recorded exploration drilling and mine workings, Tri-State zinc-lead district, Missouri, Kansas, and Oklahoma. Ann Arbor, MI: University of Michigan University Library $1955 ;$ p. 32.

[10] Datin DL, Cates DA. Sampling and analysis of chat piles in the Tar Creek Superfund Site. Oklahoma: Department of Environmental Quality 2002; p. 69.

[11] Schaider LA, Senn DB, Brabander DJ, McCarthy KD, Shine JP. Characterization of zinc, lead and cadmium in mine waste: Implications for transport, exposure and bioavailability. Environ Sci Tech 2007; 41: 4164-71.

[12] Cope CC, Becker MF, Andrews WJ, DeHay K. Streamflow, water quality and metal loads from chat leachate and mine outflow into Tar Creek, Ottawa County, Oklahoma, 2005 U.S. Geological Survey, Scientific Investigations Report 2007-5115 2008; p. 24.

[13] Wilkin RT. Metal attenuation processes at mining sites. U.S. Environmental Protection Agency. Ground Water Issue 2008; p. 13.

[14] O'Day PA, Carroll SA, Waychunas GA. Rock-water interactions controlling $\mathrm{Zn}, \mathrm{Cd}$, and $\mathrm{Pb}$ concentrations in surface waters and sediments, U. S. Tri-State mining district. 1. Molecular identification using X-ray absorption spectroscopy. Environ Sci Tech 1998; 32: 943-55.

[15] Carroll SA, O'Day PA, Piechowski M. Rock-water interactions controlling $\mathrm{Zn}, \mathrm{Cd}$, and $\mathrm{Pb}$ concentrations in surface waters and sediments, U. S. Tri-State mining district. 2. Geochemical Interpretation. Environ Sci Tech 1998; 32: 956-65.

[16] Parkhurst DL. Chemical analyses of water samples from the Picher Mining Area, Northeast Oklahoma and Southeast Kansas. U.S. Geological Survey. Open-File Report 87-453 1987; p. 43.

[17] Brown E, Skougstat MW, Fishman FJ. Methods for collection and analysis of water samples for dissolved minerals and gases. U.S. Geological Survey. Techniques of Water-Resources Investigations, Book 5, Chapter A1. 1970; p. 160.

[18] Rantz SE. Measurement and computation of streamflow: Measurement of stage and outflow, U.S. Geological Survey. WaterSupply Paper 2175 1982; vol. 1, p. 631.

[19] Wilde FD, Radtke DB, Gibs J, Iwatsubo RT, Eds. National field manual for the collection of water-quality data - Cleaning of equipment for water-quality samples. U.S. Geological Survey. Techniques of Water-Resources Investigations, book 9, chap. A3. 1998.

[20] Wilde FD, Radtke DB, Gibs J, Iwatsubo RT, Eds. National field manual for the collection of water-quality data - Collection of water-quality samples. U.S. Geological Survey. Techniques of Water-Resources Investigations, book 9, chap. A4. 1999.

[21] Skougstad MW, Fishman MJ, Friedman LC, Erdmann DE, Duncan SS. Methods for determination of inorganic substances in water and fluvial sediment. U.S. Geological Survey. Techniques of WaterResources Investigations, Book 5, Chp. A1. 1979; p. 1159.

[22] Martin TD, Brockhoff CA, Creed JT, EMMC Methods Work Group. Method 200.7: Determination of metals and trace elements in water and wastes by inductively-coupled plasma-atomic emission spectrometry. U.S. Environmental Protection Agency, Office of Research and Development, Environmental Monitoring Systems Laboratory, Cincinnati, OH . 1994; [cited 2008 Jun 30]. Available from http://www.epa.gov/waterscience/methods/method/ files/200_7.pdf/

[23] Insightful Corporation. S-Plus 7.0 for Windows Professional Developer Edition with Release 3.0 of the U.S. Geological Survey S-Plus library. Seattle, Washington: Insightful Corporation 2005.

[24] Wilcoxon F. Individual comparisons by ranking methods. Biometrics 1945; 1: 80-3.

[25] McKnight ET, Fischer RP. Geology and ore deposits of the Picher field, Oklahoma and Kansas. U.S. Geological Survey. Professional Paper 588. 1970; p. 165.

[26] Paradis S, Hannigan P, Dewing K. In: Goodfellow WD, Ed. Mississippi Valley-type lead-zinc deposits. Mineral deposits of Canada: A synthesis of Major Deposit-Types, District Metallogeny, the Evolution of Geological Provinces, and Exploration Methods. Geological Association of Canada, Mineral Deposits Division, Special Publication No. 5. 2007; p. 19.

[27] Hem JD. Study and interpretation of the chemical characteristics of natural water, U.S. Geological Survey. Water-Supply Paper 2254 1985; p. 263.

[28] Pontes-Buarque M, Tessis AC, Bonapace JAP, Monte MBM, de Souza-Barros F, Vieyra A. Surface charges and interfaces: implications for mineral roles in prebiotic chemistry. Anais da Academia Brasileira de Ciencias 2000; 72: 317-22.

[29] Lemos VP, da Costa ML, Lemos RL, de Faria MSG. Vivianite and siderite in lateritic iron crust: an example of bioreduction. Quimica Nova 2007; 30: 36-40.

[30] Nordstrom DK. In: Kittrick JA, Famming DS, Hossner LR, Eds. Aqueous pyrite oxidation and consequent formation of secondary iron minerals. The environmental geochemistry of mineral deposits, 6A. Society of Economic Geologists: Littleton Press 1982; pp. 37-56.

[31] Elder JF. Metal biogeochemistry in surface-water systems-a review of principles and concepts. U.S. Geological Survey. Circular 1013. 1988; p. 43.

[32] DeHay KL. Assessment and comparison of 1976-77 and 2002 water quality in mineshafts in the Picher mining district, northeastern Oklahoma and southeastern Kansas. U.S. Geological Survey. Water-Resources Investigations Report 03-4248. 2003; p. 64.

[33] DeHay KL, Andrews WJ, Sughru, MP. Hydrology and groundwater quality in the mine workings within the Picher mining district, northeastern Oklahoma, 2002-03. U.S. Geological Survey. Scientific Investigations Report 2004-5043. 2004; p. 62.

[34] American Water Works Association Research Foundation. Internal corrosion of water distribution systems, American Water Works Association Research Foundation. 1996; pp. 586.

[35] Morel FMM, Hering JG. Principles and applications of aquatic chemistry. New York: John Wiley and Sons 1993; p. 588.

[36] State of Oklahoma, Final report of the Chat Use Subcommittee of Governor Frank Keating's Tar Creek Superfund Task Force, Office of Secretary of Environment. 2000; p. 29.

[37] U.S. Environmental Protection Agency, Five year review of the Tar Creek Superfund site, Ottawa County, Oklahoma. U.S. Environmental Agency, Region VI, Dallas, Texas. 2008 [cited 2008 Aug 20]. Available from: http://epa.gov/earth1r6/6sf/pdffiles/ 5yeartarcreek.pdf

(c) Andrews and Masoner; Licensee Bentham Open.

This is an open access article licensed under the terms of the Creative Commons Attribution Non-Commercial License (http://creativecommons.org/licenses/ by-nc/3.0/) which permits unrestricted, non-commercial use, distribution and reproduction in any medium, provided the work is properly cited. 